\title{
Phenotypic Characteristics of Ten Garlic Cultivars Grown at Different North American Locations
}

\author{
Gayle M. Volk ${ }^{1}$ \\ National Center for Genetic Resources Preservation, U.S. Department of \\ Agriculture, ARS, 1111 S. Mason Street, Fort Collins, CO 80521
}

David Stern

Friends of Garlic, Inc., Rose, NY 14542-0149

Additional index words. Allium sativum, bulb, cultivation, diversity, environment, morphology, nutrition

\begin{abstract}
Garlic (Allium sativum L.) cultivars grown under diverse conditions have highly elastic environmental responses, particularly relating to skin color and yield. Ten diverse garlic cultivars were grown at 12 locations in the United States and Canada for 2 consecutive years to identify the environmentally responsive phenotypic traits of garlic. Clove arrangement, number of topsets, topset size, topset color, number of cloves, clove weight, clove skin color, and clove skin tightness were generally stable for each cultivar regardless of production location and conditions. Scape presence varied with cultivar and location, but for the most part, cultivars classified as hardneck types produced scapes and those classified as softnecks did not produce scapes. Bulbs grown at the northern Colorado, Minnesota, Pennsylvania, Vermont, and Washington locations were generally larger than the other locations. Soil potassium levels were positively correlated with bulb circumference and fresh weight. Soil sulfur and manganese levels were correlated with bulb sulfur and manganese content. Bulb wrapper color and intensity were highly dependent on location and cultivar. The Silverwhite cultivar was consistently white and 'Ajo Rojo', 'German White', 'Inchelium', 'Sakura', and 'Spanish Roja' were generally white with some faint violet or brown stripes or splotches across the locations. In contrast, cultivars Chesnok Red, Purple Glazer, Red Janice, and Siberian were more likely to have moderate or dark violet stripes, streaks, or splotches, particularly when grown at the northern Colorado, Minnesota, Nevada, New York, Ontario, Pennsylvania, or Washington locations. These results can help farmers identify niche regional markets that provide novel products to consumers. From these results, it was shown that garlic cultivars or classes grown under diverse conditions have highly elastic soil nutrient responses, particularly relating to skin color and yield.
\end{abstract}

Hundreds of garlic (Allium sativum L.) cultivars are available from seed companies,

\footnotetext{
Received for publication 9 Jan. 2009. Accepted for publication 19 May 2009.

This project was partially supported by the USDA-CSREES Northeast Sustainable Agriculture Research and Education Program, grant number LNE05-231.

Any mention of trade names of commercial products in this article is solely for the purpose of providing specific information and does not imply recommendation or endorsement by the U.S. Department of Agriculture.

We thank garlic growers Dr. Deborah Allan (Minnesota), Janet Bachman (Arkansas), Eugenie Doyle (Vermont), Noah Gress (Pennsylvania), Leo Keene (Kentucky), Shane LaBrake (Maryland), Dr. Walt Lyons (Colorado), Nick Milicia (Colorado), Dr. Angela O'Callaghan (Nevada), Frank Parente (Washington), Leo Keene and Jean Pitches Keene (Kentucky), Dr. Carl Rosen (Minnesota), David Stern (New York), and John Zandstra (Ontario) for participation in this project. We also appreciate the excellent technical assistance provided by Ann Caspersen.

${ }^{1}$ To whom reprint requests should be addressed; e-mail Gayle.Volk@ars.usda.gov.
}

retailers, and germplasm collections. Increasingly, bulbs intended for planting are purchased from nonlocal sources and the resulting yields can be unpredictable; garlic bulbs resulting from seed stock purchased in other regions often do not display the characteristics such as bulb size, shape, and color that were listed in the catalogs. This is a result of the high degree of variability in clove wrapper color, bulb size, yield, and flavor influenced by growth environment, cultivar, and production year (Waterer and Schmitz, 1994).

Locations differ in soil type, fertility, water availability, growing temperatures, daylength, solar radiation, and management practices. Because garlic is highly adaptive to its growth environment, yields remain consistent or may improve when bulbs are replanted in similar conditions in which they were produced (Waterer and Schmitz, 1994). As a consequence, it is frequently recommended that local garlic be purchased as planting stock or to allow several years of production for adaptation to a new environment (Engeland, 1991).

Previous work has sought to correlate some physical features of garlic with garlic type identification (Engeland, 1991, 1995; Maaß and Klaas, 1995; Volk et al., 2004). Studies that compared appearance with bulb firmness, $\mathrm{pH}$, soluble solids, moisture content, and sugar content determined that many of these traits are independent of bulb chroma and hue angles of the skin color across 14 garlic cultivars (Pardo et al., 2007). Other traits that vary across cultivars when grown under the same environmental conditions include the leaf number before bolting, flowering date, final stem length, flower/topset ratio, and pollen viability (Kamenetsky, 2007).

The continual growth and recent interest in new cuisines as well as health benefits of garlic have brought the diversity of garlic types to the attention of the public. Grocery stores frequently carry white, softneck (nonscape-producing) garlic types that are mostly imported and generally amenable to mechanized production. Alternatively, hardneck (scape-producing) types that come in various shades of purples, magentas, pinks, and whites are available at local vegetable stands and direct marketing programs. However, garlic cultivar identification is challenging as a result of its phenotypic plasticity (Al-Zahim et al., 1997; Ipek et al., 2003).

In 2004, Volk et al. published an assessment of the genetic diversity of 211 garlic cultivars. Garlic types silverskin, artichoke, rocambole, porcelain, purple stripe, marble purple stripe, and Asiatic were genetically differentiated (Volk et al., 2004). Other garlic types such as turban, creole, and glazed purple stripe were underrepresented and thus not clearly differentiated. One cultivar representing each of the 10 garlic types listed here was selected to best capture the genetic diversity available within Allium sativum to identify the range of phenotypic responses observed at diverse growth locations in a 2-year project.

We report on the variation observed in bulb elemental composition and morphological characteristics of the 10 garlic cultivars across the diverse growth locations. We identify stable traits that can serve as useful indicators for garlic type classification on a national scale to increase the standardization of garlic classification terminology.

\section{Materials and Methods}

Plant materials. In 2005, garlic bulbs from 10 cultivars (Table 1) obtained from producers in Washington state were distributed to 10 garlic growers who practiced sustainable production methods with minimal, if any, chemical inputs (Table 2; Fig. 1; Engeland, 1991, 1995). Small-scale garlic farmers were provided with planting stocks from the same original sources and were asked to grow them on their farms for 2 consecutive years using their best practices. At each location, 16 cloves per cultivar were planted in each of three replicate plots in randomized complete block designs under standard cultivation conditions for the growth environment. Bulbs were harvested 
Table 1. Means and ses for bulb fresh weight and circumference as well as firmness and quality information collected for five bulbs representing each of 10 garlic cultivars provided to growers in 2005 .

\begin{tabular}{|c|c|c|c|c|c|c|}
\hline Cultivar & Type & Bulb wrapper color & $\begin{array}{l}\text { Bulb } \\
\text { fresh weight }(\mathrm{g})\end{array}$ & $\begin{array}{c}\text { Bulb } \\
\text { circumference }(\mathrm{cm})\end{array}$ & Bulb firmness & $\begin{array}{l}\text { Quality, as perceived by } \\
\text { grower participants }\end{array}$ \\
\hline Ajo Rojo & Creole & White & $53.7 \pm 3.4$ & $18.2 \pm 0.5$ & Firm & Excellent \\
\hline Chesnok Red & Purple stripe & Light violet stripe & $68.2 \pm 3.3$ & $19.2 \pm 0.3$ & Very firm & Good \\
\hline German White & Porcelain & White/light violet stripe & $89.6 \pm 1.7$ & $20.7 \pm 0.2$ & Very firm & Good \\
\hline Inchelium & Artichoke & White/light violet splotch & $81.9 \pm 8.4$ & $21.3 \pm 1.0$ & Very firm & Good \\
\hline Purple Glazer ${ }^{z}$ & Glazed purple stripe & White/light violet stripe & $57.3 \pm 1.7$ & $18.9 \pm 0.4$ & Fair-good & Fair to good \\
\hline Red Janice & Turban & Light-moderate violet stripe & $53.2 \pm 3.2$ & $18.7 \pm 0.4$ & Very firm & Good \\
\hline Sakura & Asiatic & White/light violet stripe & $47.1 \pm 4.2$ & $17.9 \pm 0.5$ & Firm & Good \\
\hline Siberian & Marble purple stripe & White/light-moderate violet stripe & $77.3 \pm 6.1$ & $20.6 \pm 0.6$ & Very firm & Good \\
\hline Silverwhite & Silverskin & White & $57.7 \pm 1.8$ & $17.7 \pm 0.1$ & Very firm & Good \\
\hline$\underline{\text { Spanish Roja }}$ & Rocambole & White & $45.7 \pm 1.9$ & $17.2 \pm 0.2$ & Fair-good & Poor \\
\hline
\end{tabular}

${ }^{\mathrm{z}}$ Glazed purple stripe Red Rezan was provided to the Washington grower.

when the lower one-third to one-half of the leaves on the plants had dried. A subset of six to eight bulbs for each cultivar in each replicate plot was returned to $\mathrm{Ft}$. Collins, $\mathrm{CO}$, for data collection and analysis. In the fall of 2006, bulbs produced at each farm were replanted and grown for a second season at the same farm (except for a change in the Colorado farm from Ft. Collins to Colorado Springs and the addition of a farm in Ontario, Canada, from planting stock grown at the Pennsylvania location in 2005). In 2007, six to eight bulbs of each cultivar from the replicate plots were sent to Ft. Collins, CO, for phenotypic characterization. Grower participants were asked to provide feedback to the project in the form of digital documentation, surveys, planting notes, and harvest notes. Locations, USDA hardiness zones, and production practices were documented (Table 2) (Cathey, 1990).

Soil tests. Triplicate soil surface samples were collected from two or three plots at each field site at planting in 2005 and 2006 and at harvest in 2006 and 2007. Samples were sent directly to the Harris AgSource Testing Laboratory (Lincoln, NE) for determination of soil $\mathrm{pH}$, soluble salt, cation exchange capacity, percent base saturation (hydrogen, sodium, magnesium, calcium, and potassium), organic matter composition, nitrate-nitrogen, and elemental composition [phosphorus (Bray $\mathrm{P}$ when $\mathrm{pH}<7.1$ and Olsen $\mathrm{P}$ when $\mathrm{pH}>7.2$ ), potassium, zinc, manganese, copper, iron, sulfur, boron, calcium, magnesium, sodium]. Data from all soil test results were included in the calculation of averages for each field site.

Phenotypic data collection. Field data and photographs were collected by the site growers. Bulb and clove data were collected from three representative bulbs from each plot from each location in a standardized manner in Ft. Collins, CO. Phenotypic data collected from field samples included: bulb wrapper color, color pattern on skin, circumference, and fresh weight (FW) of bulbs; presence/absence of stalk within bulb; number, color, and size of topsets; and number, weight, arrangement, and skin color of cloves.

Bulb composition. After removing skin, cloves were stored in a $-80{ }^{\circ} \mathrm{C}$ freezer and then freeze-dried. After moisture estimation (difference between clove weight before and after freeze drying), cloves were ground and sifted through a screen with 64 squares $/ \mathrm{cm}^{2}$
(40 mesh). Ground samples were composed of cloves from bulbs selected to be representative from each plot (with each cultivar, site, and replicate analyzed separately). Samples from bulbs for each harvest year were analyzed for element content by inductively coupled plasma mass spectrometry at the AgSource Harris Laboratories (Lincoln, NE).

Statistical analyses. Analyses of variance and Tukey means separation tests $(\alpha<0.05)$ using JMP software (SAS Institute, Cary, NC) were used to compare quantitative data obtained from soil tests, bulb elemental composition analyses, and bulb, clove, and topset phenotypic traits. Multivariate analyses (Spearman's $\rho$ ) in the JMP software identified significant nonparametric correlations between variables. Qualitative data were summarized based on observations of bulbs for each cultivar from each replicate at each site. Data from multiple years were combined in a single analysis when the main effects resulting from year were not significant.

\section{Results}

Quality of planting stock. Planting stock of the 10 cultivars was distributed to the participants to ensure initial genetic uniformity and quality. Cultivars Ajo Rojo, Chesnok Red, German White, Red Janice, Sakura, Siberian, and Silverwhite were considered to be of high initial quality (based on firmness, size, and no evidence of disease) based on participant surveys. The quality of cultivars Inchelium, Purple Glazer, and Spanish Roja at the time of planting was lower (some cloves exhibited signs of Fusarium sp. Link ex Gray) than that of the other cultivars, but adequate quantities of acceptable planting cloves were available.

Bulb characteristics. Bulbs generally retained their softneck or hardneck phenotypes at the various growth locations, but there were some exceptions. Initially, 'Inchelium' and 'Silverwhite' were the only two softneck cultivars provided to the participants. However, some cultivars did not exhibit the central stalk characteristics of hardneck cultivars during the subsequent field trials. Some bulbs of 'Ajo Rojo' grown in Nevada and Vermont, 'Red Janice' and 'Sakura' grown in Kentucky, and 'Sakura' grown in Nevada were harvested as softneck garlic types. In addition, some 'Silverwhite' bulbs harvested in Maryland were classified as hardneck.

Scape structure and topset characteristics are two morphological garlic characteristics that were of interest (Table 3). The softneck garlic cultivars Inchelium and Silverwhite sometimes produced partial scapes within the stems, whereas the hardneck cultivars had scapes that emerged and curled in various arrangements (except for 'Sakura', which generally had a straight scape). Scape curl data were not consistently collected across the locations and were therefore not included in analyses. Topset characteristics also varied greatly among cultivars but remained stable regardless of growth environment. Cultivars that produced 100 to 200 topsets per umbel ('Ajo Rojo', 'Chesnok Red', 'German White', 'Purple Glazer') had topsets that were similar in size to grains of rice and those that produced between 10 and 50 topsets per umbel had either corn ('Red Janice', 'Siberian', and 'Spanish Roja') or marble ('Sakura') -sized topsets. Most cultivars had violet-colored topsets, but 'German White' had white topsets and 'Red Janice', 'Sakura', and 'Spanish Roja' had topsets that were consistently brown or brown/violet (Table 3).

Soil analyses. Soil conductivity ranged from lows of 0.25 and $0.27 \mathrm{mmhos} / \mathrm{cm}$ in Kentucky and southern Colorado, respectively, to $2.08 \mathrm{mmhos} / \mathrm{cm}$ in northern Colorado (Table 4 ). The cation exchange capacity (CEC) values obtained are representative of loamy sand, silty loam, and loam soil types. The CEC ranged from $10.8 \%$ in Maryland to $24.5 \%$ and $33.3 \%$ in Nevada and northern Colorado, respectively. The northern Colorado and Nevada plots were both grown in raised beds with overhead irrigation. All the sites had a CEC dominated by calcium (59\% to $92 \%$ ). Northern Colorado, Minnesota, Nevada, Pennsylvania, and Washington also had significant $\mathrm{Mg} \%$ (16.6 to 23.1), $\mathrm{K} \%$ (3.84 to 9.5$)$, or $\mathrm{Na} \%$ (0.44 to 8.52) CEC composition. The soils of Arkansas, Maryland, and Vermont had higher $\mathrm{H} \%$ (15 to 19 ) and lower levels of $\mathrm{Mg} \%$ (9.4 to 14.1).

Soil organic matter content ranged from $3 \%$ to $10 \%$ and the soil $\mathrm{pH}$ level was between 6 and 8 , within the recommended ranges for garlic production (Table 5; Rosen et al., 2008). High nitrate-nitrogen levels were found in Washington and Maryland. Phosphorus levels were highest in northern Colorado (462 ppm, 


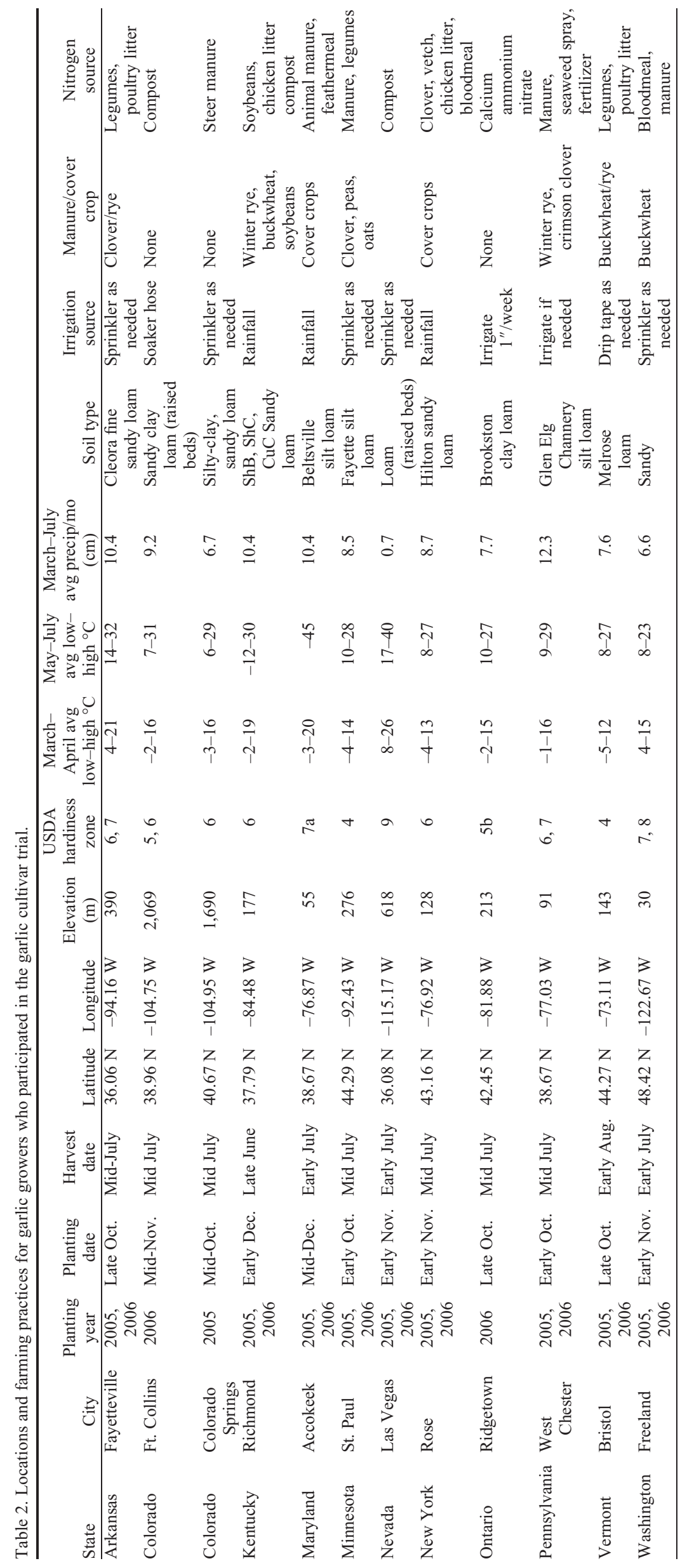

Olsen method), Washington (461 ppm, Bray method), and Minnesota (307 ppm, Bray method). Boron ranged from $0.58 \mathrm{ppm}$ (Arkansas) to $2.2 \mathrm{ppm}$ (northern Colorado), copper ranged from $0.6 \mathrm{ppm}$ (New York) to $2.7 \mathrm{ppm}$ (Arkansas), manganese ranged from $1.9 \mathrm{ppm}$ (Ontario) to $16 \mathrm{ppm}$ (Arkansas), and zinc ranged from $1.2 \mathrm{ppm}$ (Kentucky) to $17.1 \mathrm{ppm}$ (Washington). Iron levels were highest in Maryland and Minnesota (101.2 and $112 \mathrm{ppm}$, respectively) and lowest in Nevada, southern Colorado, and northern Colorado (13 ppm, 29 ppm, and 29.6 ppm, respectively). Sulfur levels were generally between 9 and 21 ppm; however, sulfur levels were 41 ppm in Maryland, 54 ppm in Nevada, and $368 \mathrm{ppm}$ in Colorado with a greater than 40-fold difference between the highest and lowest soil sulfur content (Table 5). High soil nutrient levels in Colorado may have resulted from the compost source as well as the well irrigation water.

Bulb wrapper color. Bulb wrapper color and pattern were highly variable among cultivars across locations (Table 6). 'Silverwhite' was white without patterning regardless of its growth location. The remaining nine cultivars were more plastic in their color response to the environment. Across the locations, 'Ajo Rojo', 'German White', 'Inchelium', 'Sakura', and 'Spanish Roja' were generally white with some faint violet or brown stripes or splotches. Cultivars Chesnok Red, Purple Glazer, Red Janice, and Siberian were more likely to have moderate or dark stripes or streaks or splotches. However, the intensity of the skin patterns was highly dependent on location.

Intensity of bulb color was classified on a 1 to 4 scale and correlations were performed to identify positive correlations between intensity and the soil nutrient levels. No significant correlations were identified (data not shown). However, some general trends were noted. Most of the bulbs grown in Arkansas, southern Colorado, Kentucky, Maryland, and Vermont were shades of white with faint violet or brown stripes or splotches. In contrast, 'Chesnok Red', 'Purple Glazer', 'Red Janice', and 'Siberian' bulbs from Ontario, northern Colorado, Minnesota, Nevada, New York, Pennsylvania, and Washington were likely to have more intense violet or brown coloration (Table 6). The cause of these color variations is not known.

Bulb yield. Bulb size, measured by either FW or circumference, was highly dependent on growth location with some sites producing larger bulbs overall than other sites. The year-by-cultivar interaction was not significant, so data were pooled for each site for the harvest years 2006 and 2007. Bulbs from northern Colorado, Minnesota, Pennsylvania, Vermont, and Washington had among the largest bulbs for at least half of the cultivars (Tables 7 and 8). As expected, bulb circumference and FW were highly correlated. Circumference, FW, and clove FW were positively correlated with soil potassium levels (Table 9). 


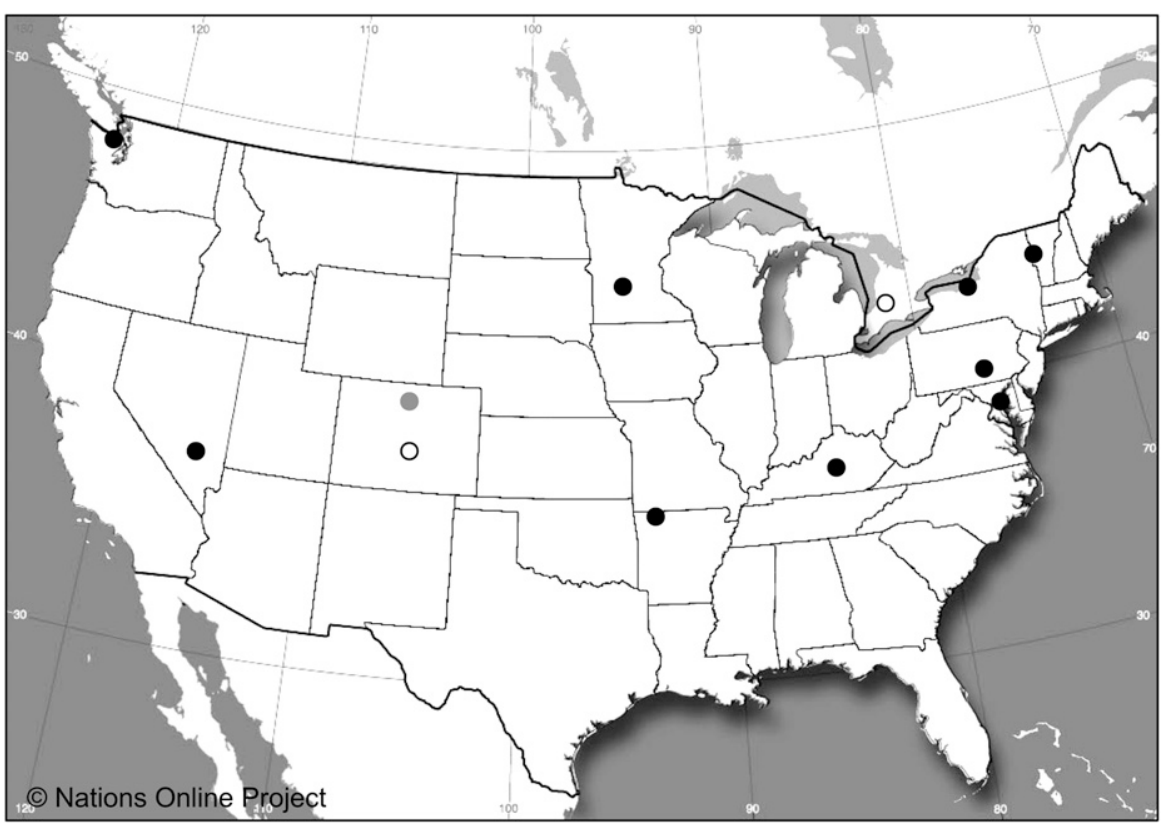

Fig. 1. Locations of garlic field sites for both 2006 and 2007 harvest seasons (•), only 2006 harvest season (०), and only 2007 harvest season $(O)$.

Regional differences with respect to bulb size were observed. In the northeast, 'Inchelium', 'Siberian', 'Silverwhite', and 'Sakura' from Vermont and New York had large bulbs with respect to circumference and fresh weight (Tables 7 and 8). 'Silverwhite' and
'Siberian' were the highest yielding in Ontario. In Pennsylvania, 'Ajo Rojo', 'Chesnok Red', 'German White', 'Inchelium', 'Purple Glazer', 'Red Janice', 'Silverwhite', and 'Spanish Roja' bulbs were among the largest observed overall. In Minnesota, 'Chesnok Red', 'German White', 'Inchelium', 'Siberian', 'Purple Glazer', 'Sakura', and 'Silverwhite' produced bulbs that could be sold commercially. In 2006, the most productive garlic cultivars in northern Colorado were Chesnok Red, German White, Inchelium, Purple Glazer, Red Janice, Sakura, Siberian, Silverwhite, and Spanish Roja. The southern Colorado location generally had lower yields in 2007 than the harvest in 2006 from northern Colorado. The raised beds used by the Nevada growers were favorable for 'Ajo Rojo', 'German White', 'Inchelium', 'Purple Glazer', and 'Red Janice' and Arkansas field conditions favored 'Siberian', 'Inchelium', and 'Red Janice'. In western Washington, all the cultivars except 'Spanish Roja' produced bulbs that could be sold at local markets with bulb yields among the highest observed in the study. Because the project had a limited number of North American locations represented, specific cultivar recommendations for each location are not provided.

Clove characteristics. Cultivars were classified according to the number of cloves

Table 3. Phenotypic characteristics that remained consistent across growth locations and years for 10 garlic cultivars grown at 12 North American locations.

\begin{tabular}{|c|c|c|c|c|c|c|c|c|c|c|}
\hline Variety & Class & $\mathrm{HN} / \mathrm{SN}^{\mathrm{z}}$ & $\begin{array}{c}\text { Clove } \\
\text { arrangement }\end{array}$ & $\begin{array}{l}\text { Topset } \\
\text { no. }\end{array}$ & $\begin{array}{l}\text { Topset } \\
\text { size }\end{array}$ & Topset color & $\begin{array}{l}\text { Clove } \\
\text { no. }\end{array}$ & $\begin{array}{l}\text { Clove } \\
\text { wt }(g)\end{array}$ & Clove color & $\begin{array}{c}\text { Clove skin } \\
\text { tightness }\end{array}$ \\
\hline Ajo Rojo & Creole & $\mathrm{HN}$ & Single & $100-200$ & Rice & $\begin{array}{l}\text { White with } \\
\text { some purple }\end{array}$ & $8-10$ & $2-4$ & $\begin{array}{l}\text { Red/purple lower and } \\
\text { white/pale upper }\end{array}$ & Moderate \\
\hline Chesnok Red & Purple stripe & $\mathrm{HN}$ & Single & $100-200$ & Rice & $\begin{array}{l}\text { Brown, violet, } \\
\text { or white }\end{array}$ & $8-10$ & $2-4$ & $\begin{array}{l}\text { Dark, streaks of brown, } \\
\text { violet, or white }\end{array}$ & Moderate \\
\hline German White & Porcelain & $\mathrm{HN}$ & Single & $100-200$ & Rice & Brown or white & $4-6$ & $6-8$ & $\begin{array}{l}\text { Light cloves with flecks or } \\
\text { streaks of brown or violet }\end{array}$ & Moderate \\
\hline Inchelium & Artichoke & SN & 2-6 layers & $\mathrm{N} / \mathrm{A}^{\mathrm{y}}$ & N/A & White & $10-12$ & $2-4$ & $\begin{array}{l}\text { White cloves with } \\
\text { yellow/brown }\end{array}$ & Snug \\
\hline Purple Glazer & $\begin{array}{l}\text { Glazed } \\
\text { purple stripe }\end{array}$ & $\mathrm{HN}$ & single & $100-200$ & Rice & Brown or violet & $8-10$ & $2-4$ & $\begin{array}{l}\text { Dark violet with some } \\
\text { brown streaks }\end{array}$ & Loose \\
\hline Red Janice & Turban & $\mathrm{HN}$ & Single & $10-50$ & Corn & Brown or white & $8-10$ & $2-4$ & Brown/white & Snug \\
\hline Sakura & Asiatic & $\mathrm{HN}$ & Single & $10-50$ & Marble & White & $4-6$ & $6-8$ & White to yellow & Loose \\
\hline Siberian & $\begin{array}{l}\text { Marble } \\
\text { purple stripe }\end{array}$ & $\mathrm{HN}$ & Single & $10-50$ & Corn & $\begin{array}{l}\text { White, brown, } \\
\text { or violet }\end{array}$ & $4-6$ & $6-8$ & $\begin{array}{l}\text { Dark with white, brown, } \\
\text { or violet streaks }\end{array}$ & Moderate \\
\hline Silverwhite & Silverskin & $\mathrm{SN}$ & 2-6 layers & N/A & N/A & White & $14-16$ & $2-4$ & White cloves with pink & Snug \\
\hline Spanish Roja & Rocambole & $\mathrm{HN}$ & Single & $10-50$ & Corn & Brown or white & $8-10$ & $2-4$ & Brown/white & Loose \\
\hline
\end{tabular}

${ }^{\mathrm{z}} \mathrm{HN}=$ hardneck; $\mathrm{SN}=$ softneck.

${ }^{\mathrm{y}} \mathrm{N} / \mathrm{A}=$ not available.

Table 4. Cation exchange capacity components for soil samples collected at 12 garlic field sites.

\begin{tabular}{|c|c|c|c|c|c|c|c|}
\hline State & $\mathrm{N}$ & $\begin{array}{l}\text { Cation exchange } \\
\text { capacity value }\end{array}$ & Calcium (\%) & Hydrogen $(\%)$ & Magnesium (\%) & Potassium (\%) & Sodium $(\%)$ \\
\hline Arkansas & 8 & $15.2 \pm 0.8$ & $69.1 \pm 2.3$ & $15.3 \pm 1.0$ & $11.1 \pm 0.9$ & $4.1 \pm 0.4$ & $0.5 \pm 0.1$ \\
\hline Colorado (2006) & 5 & $33.3 \pm 1.8$ & $70.6 \pm 2.0$ & $\mathrm{~N} / \mathrm{A}^{\mathrm{z}}$ & $17.1 \pm 0.2$ & $3.8 \pm 0.5$ & $8.5 \pm 2.2$ \\
\hline Colorado (2007) & 4 & $13.8 \pm 0.6$ & $85.0 \pm 0.3$ & N/A & $10.6 \pm 0.1$ & $3.9 \pm 0.3$ & $0.5 \pm 0.1$ \\
\hline Kentucky & 2 & $13.8 \pm 2.3$ & $80.4 \pm 6.9$ & $12.4 \pm 0.0$ & $9.6 \pm 0.5$ & $3.7 \pm 1.2$ & $0.3 \pm 0.1$ \\
\hline Maryland & 7 & $10.8 \pm 0.7$ & $62.4 \pm 3.5$ & $16.5 \pm 2.6$ & $14.1 \pm 1.1$ & $5.8 \pm 0.5$ & $1.2 \pm 0.5$ \\
\hline Minnesota & 9 & $14.1 \pm 0.6$ & $58.8 \pm 0.8$ & $13.1 \pm 0.9$ & $17.3 \pm 0.2$ & $9.5 \pm 0.3$ & $1.3 \pm 0.1$ \\
\hline Nevada & 2 & $24.5 \pm 1.0$ & $72.1 \pm 2.0$ & N/A & $20.7 \pm 0.5$ & $5.8 \pm 1.2$ & $1.6 \pm 0.4$ \\
\hline New York & 9 & $14.0 \pm 0.5$ & $88.6 \pm 1.0$ & $\mathrm{~N} / \mathrm{A}$ & $9.2 \pm 0.9$ & $2.0 \pm 0.2$ & $0.2 \pm 0.4$ \\
\hline Ontario & 4 & $19.6 \pm 0.4$ & $92.2 \pm 0.3$ & N/A & $4.9 \pm 0.1$ & $2.6 \pm 0.3$ & $0.3 \pm 0.1$ \\
\hline Pennsylvania & 9 & $13.8 \pm 0.6$ & $71.7 \pm 1.6$ & $11.2 \pm 1.7$ & $16.6 \pm 0.4$ & $8.8 \pm 0.5$ & $0.4 \pm 0.1$ \\
\hline Vermont & 9 & $11.8 \pm 0.5$ & $66.7 \pm 2.6$ & $19.1 \pm 2.8$ & $9.4 \pm 0.6$ & $6.4 \pm 0.3$ & $0.5 \pm 0.1$ \\
\hline Washington & 9 & $18.4 \pm 1.0$ & $61.0 \pm 0.8$ & $11.2 \pm 1.1$ & $23.1 \pm 0.6$ & $8.2 \pm 1.1$ & $1.5 \pm 0.4$ \\
\hline
\end{tabular}

${ }^{\mathrm{z}} \mathrm{N} / \mathrm{A}=$ not available. 


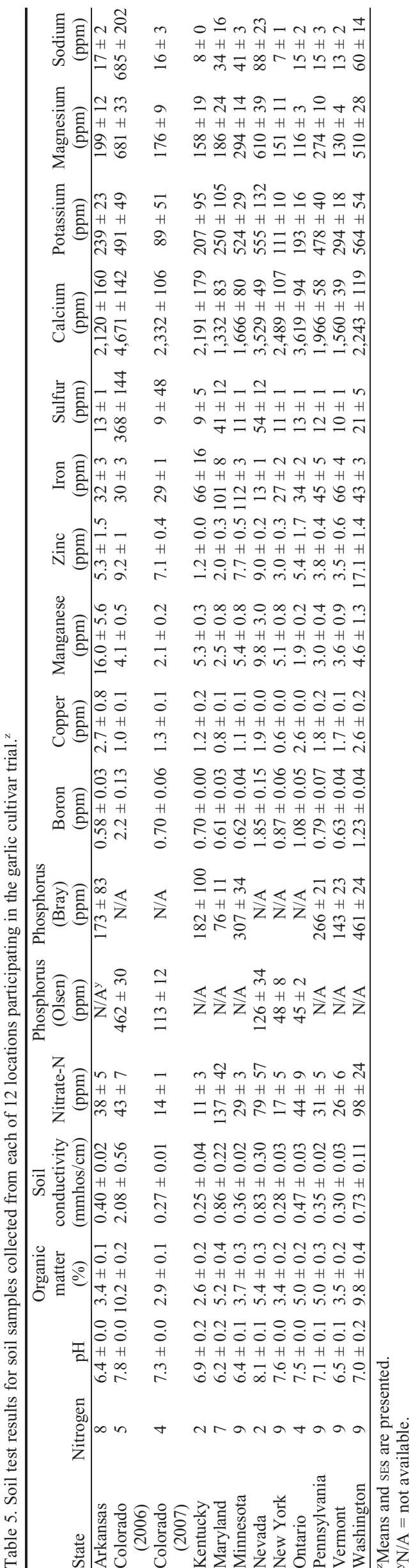

per bulb. 'Sakura', 'Siberian', and 'German White' had four to six cloves per bulb; 'Ajo Rojo', 'Chesnok Red', 'Purple Glazer', 'Red Janice', and 'Spanish Roja' had eight to 10 cloves per bulb; and 'Inchelium' and 'Silverwhite' had more than 10 cloves per bulb. Clove wrapper tightness varied from snug to loose (Table 3). A significant correlation between the number of cloves and the clove fresh weight was identified (Table 9).

Clove skin colors were consistent for specific cultivars regardless of location (Table 3 ). The clove skins of 'Ajo Rojo' were redpurple on the basal end with white or lightcolored upper portions. 'Chesnok Red' clove skins were darkly pigmented with streaks of brown, violet, or white. Similar to 'Chesnok Red', 'Purple Glazer' clove skins were darkly colored violet with some brown streaks present. Likewise, 'Siberian' clove skins were dark with white and brown streaks, often including violet. In contrast, 'German White' clove skins were very pale white with light flecks or streaks of brown or violet. 'Inchelium' and 'Silverwhite' both had white clove skins with 'Inchelium' clove skins exhibiting a tinge of yellow or brown and 'Silverwhite' clove skins appearing more pink. 'Sakura' clove skins ranged from white to yellow. Cultivars Red Janice and Spanish Roja both had clove skins that ranged in shades of brown and white.

Bulb elemental composition. Elemental composition data were combined for all the cultivars in each site because the state $x$ cultivar and year $\times$ cultivar interactions were not significant in the analysis of variance model. Bulb elemental analyses were significantly different across years, and the average results from both the 2006 and 2007 harvests are provided for each location (Table 10). The range of values (on a dry weight basis) obtained after elemental analyses were performed on freeze-dried bulbs revealed consistent levels (less than twofold difference) across locations for the elements boron, magnesium, phosphorus, potassium, and nitrate-nitrogen. Nevada bulbs were high in potassium, sulfur, and zinc and northern Colorado bulbs were high in sodium (Table 10). Significant correlations were identified between the soil manganese level and bulb manganese content as well as the soil sulfur level and bulb sulfur content (Table 9).

\section{Discussion}

The primary purpose of this research was to determine phenotypic traits that are stable and those that vary with growth location. We have shown that traits such as clove number, clove skin coloration, and topset number are representative of cultivar type across growth locations, whereas phenotypic traits such as bulb wrapper color, bulb size, and bulb elemental composition were specific to sites.

Hundreds of garlic cultivars have been characterized in genebanks and research programs (Jenderek and Hannan, 2004; Kamenetsky et al., 2005; Panthee et al., 2006; Stavelikova, 2008). High levels of 


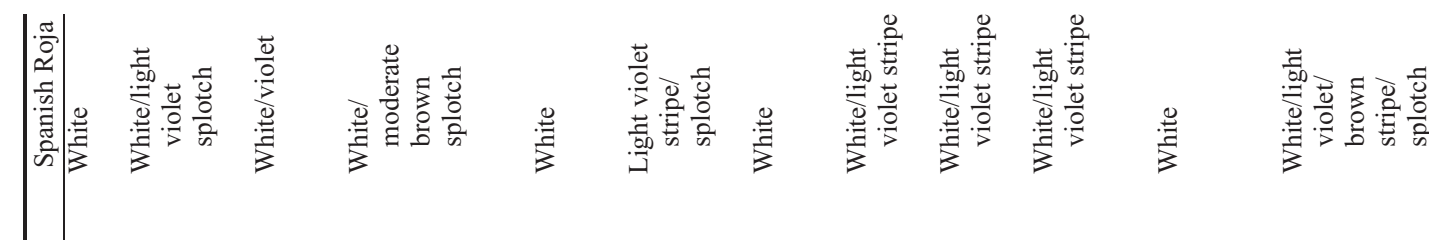

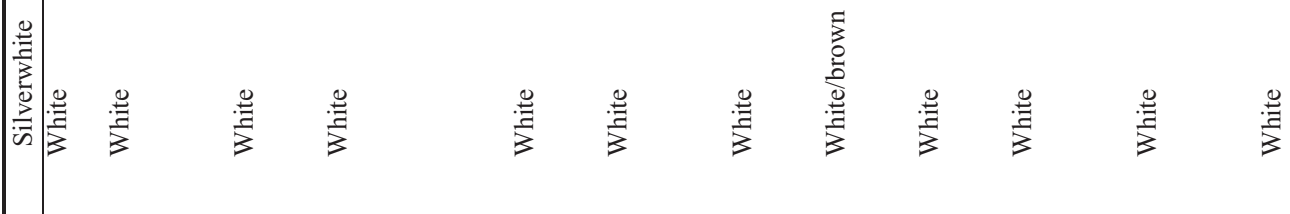

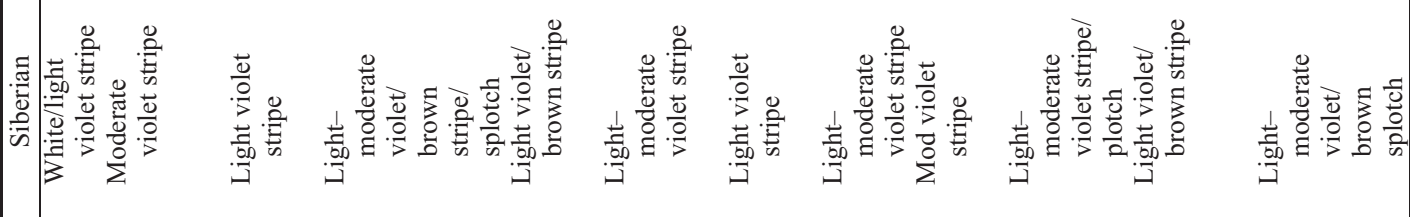

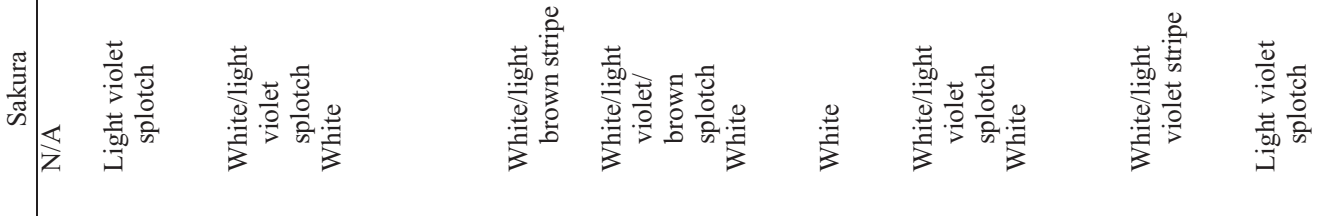

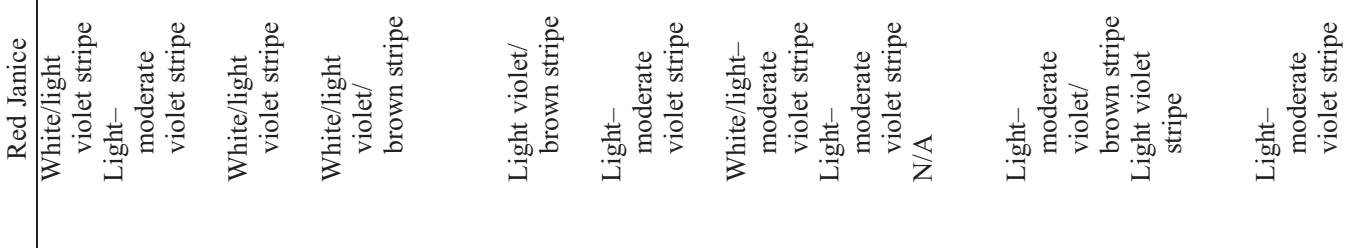

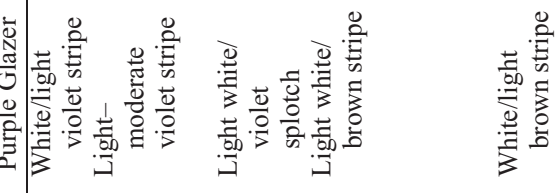

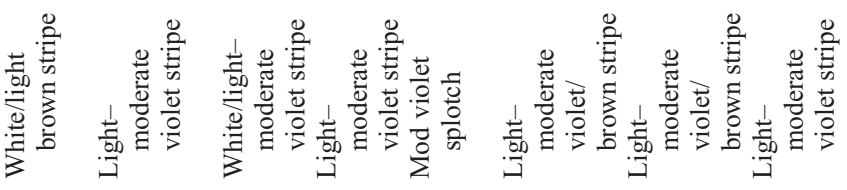




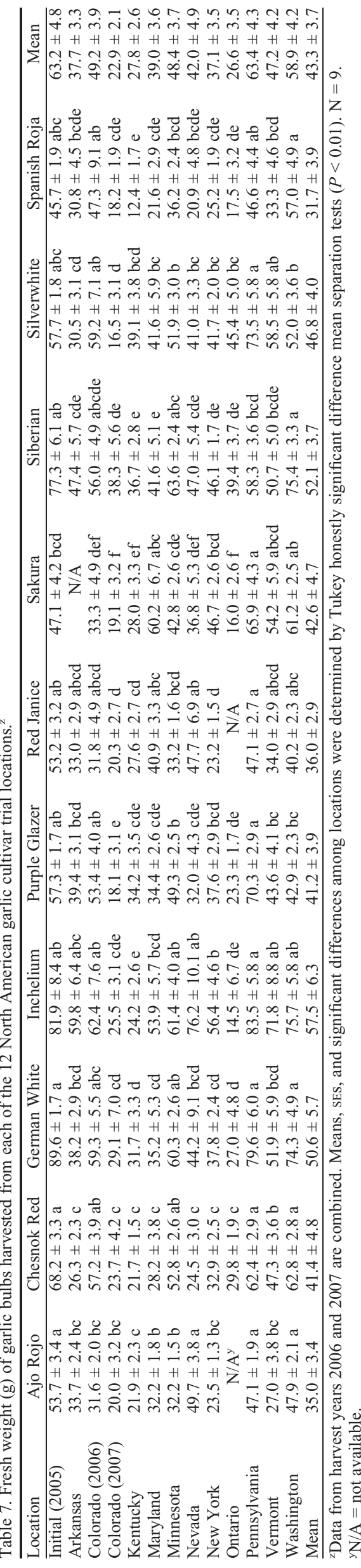

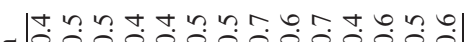

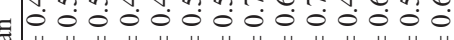

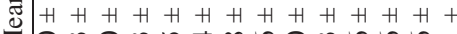

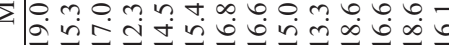
$\pi$

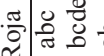

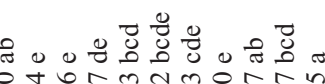

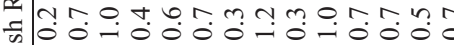
而H H H H H H H H H H H H H

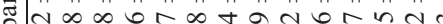

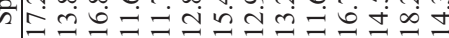

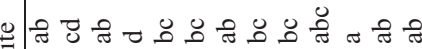
है

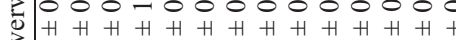
的

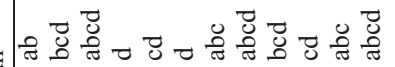

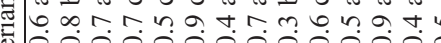

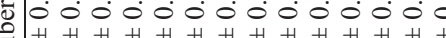
n $60 \mathrm{mn}$ a 드은

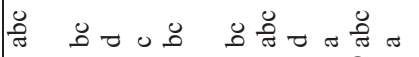

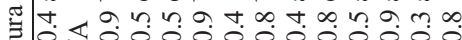

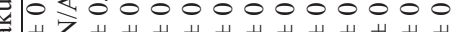
党 $\mathrm{H}+\mathrm{H}+\mathrm{H}+\mathrm{H} H+H+H+H+H+H$

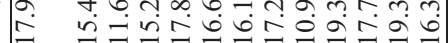

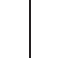

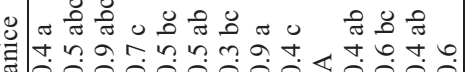

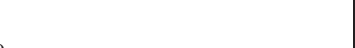
$H+H+H+H+H \quad H+h$

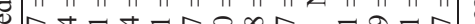

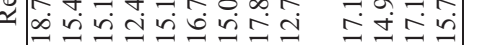

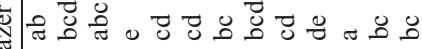

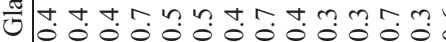
$\triangle$ H H H H H H H H H H H H H

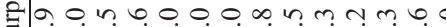

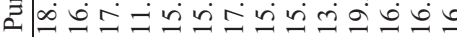

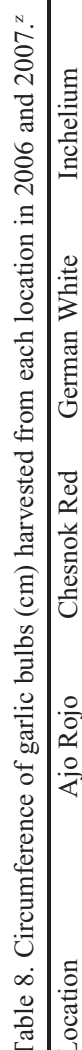

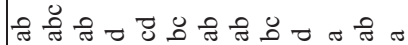

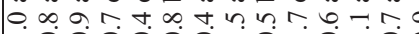
- $0000000-0-0=0$ H H H H H H H H H H H H H H

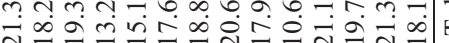

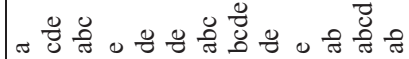

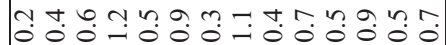
H H H H H H H H H H H H H H

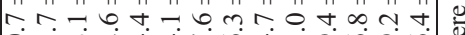

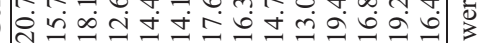

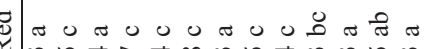
m喵 $H+H+H+H+H+H+H+H+H$ - mo tom mncom no no aํ்

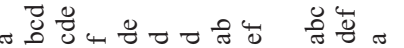

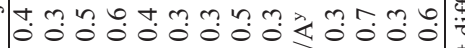
H H H H H H H H H Z H H H H

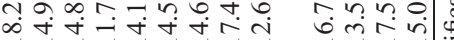

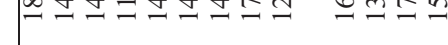

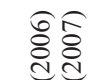
. 를

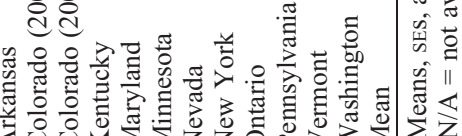

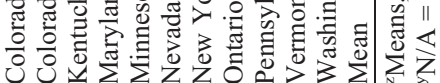

diversity within collections have been identified using genetic fingerprinting techniques (Ipek et al., 2003; Lampasona et al., 2003; Pooler and Simon, 1993a; Volk et al., 2004). Of particular interest are the garlic types most similar to those found in Central Asia that successfully produce seeds (Kamenetsky and Rabinowitch, 2001; Shemesh et al., 2008). Garlic seed production is of great interest because genetic recombination events reveal novel forms of diversity and also because seeds can be used for production (Jenderek and Hannan, 2004; Kamenetsky et al., 2005; Shemesh et al., 2008). Topset diversity and development for diverse cultivars has been previously reported with a focus on fertility (Etoh, 1985; Kamenetsky and Rabinowitch, 2001; Kamenetsky et al., 2004, 2005).

Multiple groups have proposed garlic classification schemes based on phenotypic characters, including scape curl, clove skin tightness, topset production, leaf architecture, leaf color, bulb wrapper color, clove number, and clove arrangement (Engeland, 1991; 1995; Hanelt, 2001; Keller, 2002; Maaß and Klaas, 1995) and summarized by Volk et al. (2004) as well as Kamenetsky (2007). However, it remains difficult to classify garlic cultivars using the existing terminology.

Research programs aimed at evaluating the diversity of garlic collections have assessed traits such as the number of cloves per bulb, bulb weight, skin color, flowers per umbel, flower color, anther color, and scape length of cultivars grown in a common garden environment (Pooler and Simon, 1993b). Other garlic collections have been evaluated on traits including outer skin color, clove skin color, number of cloves per bulb, bulb structure type, shape of the compound bulb in a horizontal section, 100 topset weight, number of topsets, weight of cloves, ability to flower, hard/soft neck, daylength requirement, time of flowering, topset color, leaf number, leaf color, leaf width, length of longest leaf, and the cross-section of the leaf (IPGRI, ECP/GR, AVRDC, 2001). In contrast, varietal evaluations focus on percent emergence, plant height, leaf width, leaf length, neck diameter, bulb diameter, harvest date, yield, bulb weight, and percent bolting (Dickerson and Wall, 1997).

High yields are dependent on having initial planting stock that is of sufficient size and quality. In garlic, this can be a challenge as a result of the high incidence levels of pathogens and viruses in production fields (Conci et al., 2003; Lot et al., 1998; Melo et al., 2006). Despite obtaining planting stock from reliable sources, the initial planting quality of 'Spanish Roja', in particular, was lower than expected. The quality of the initial bulbs may have affected the resulting yields of 'Spanish Roja'.

A set of cultivar-specific traits would aid in market recognition and cultivar identification. Although it was not possible to include multiple cultivars representing each garlic type at the sites included in this project, it is possible to ascertain which phenotypic 
Table 9. Positive nonparametric Spearman correlations between bulb and soil characteristics. ${ }^{\mathrm{z}}$

\begin{tabular}{lccccc}
\hline & $\begin{array}{c}\text { Bulb } \\
\text { element level }\end{array}$ & $\begin{array}{c}\text { Bulb } \\
\text { circumference }\end{array}$ & $\begin{array}{c}\text { Bulb } \\
\text { fresh wt }\end{array}$ & $\begin{array}{c}\text { Number } \\
\text { cloves/bulb }\end{array}$ & $\begin{array}{c}\text { Clove } \\
\text { fresh wt }\end{array}$ \\
\hline Bulb circumference & N/A & 1 & $<0.0001$ & 0.0001 & $<0.0001$ \\
Bulb fresh weight & N/A & $<0.0001$ & 1 & 0.0011 & $<0.0001$ \\
Number of cloves/bulb & N/A & 0.0001 & 0.0011 & 1 & 0.0117 \\
Clove fresh weight & N/A & $<0.0001$ & $<0.0001$ & 0.0117 & 1 \\
Perrcent organic matter & N/A & 0.1149 & 0.0655 & 0.2504 & 0.0858 \\
Soluble salts & N/A & 0.5137 & 0.5591 & 0.4094 & 0.6012 \\
Cation exchange capacity & N/A & 0.7103 & 0.6943 & 0.9659 & 0.6733 \\
Soil boron & 0.9175 & 0.9544 & 0.9488 & 0.7859 & 0.9090 \\
Soil calcium & 0.7807 & 0.4591 & 0.3631 & 0.9829 & 0.2830 \\
Soil copper & 0.9602 & 0.7615 & 0.8110 & 0.5207 & 0.9375 \\
Soil iron & 0.8979 & 0.2264 & 0.1608 & 0.5138 & 0.0897 \\
Soil magnesium & 0.7256 & 0.1408 & 0.2264 & 0.0413 & 0.3326 \\
Soil manganese & 0.0252 & 0.8641 & 0.4953 & 0.4907 & 0.4159 \\
Soil nitrate & 0.1610 & 0.0928 & 0.2293 & 0.0753 & 0.0217 \\
Soil phosphorus & 0.3341 & 0.1044 & 0.1451 & 0.0615 & 0.1904 \\
Soil potassium & 0.0949 & 0.0201 & 0.0249 & 0.0944 & 0.0244 \\
Soil sodium & 0.3963 & 0.6420 & 0.6318 & 0.4680 & 0.6733 \\
Soil sulfur & 0.0292 & 0.4928 & 0.6471 & 0.6087 & 0.6419 \\
Soil zinc & 0.8138 & 0.3142 & 0.4656 & 0.3649 & 0.3949 \\
\hline Significan & & & & &
\end{tabular}

${ }^{\mathrm{z}}$ Significance levels of probabilities $>[\rho]$ are presented

y Specific bulb elements correspond to the soil elements.

${ }^{\times} \mathrm{N} / \mathrm{A}=$ not applicable.

characteristics are cultivar-specific regardless of growth location. Traits, including clove arrangement, number of topsets, topset size, topset color, number of cloves, clove weight, clove color, and clove skin tightness, were traits that were cultivar-specific among the diverse locations and farming practices. In future projects, further investigation of scape curl patterns would also be of interest. Using these traits, it was possible to differentiate all the cultivar types except 'Chesnok Red' and 'Purple Glazer' (Purple Stripe and Glazed Purple Stripe classification, respectively) (Table 3). These traits are likely to be of use for the characterization of garlic types within large genebank collections.

Scape production is the key characteristic that differentiates hardneck and softneck garlic types. In most cases, softneck-type cultivars failed to form scapes and hardneck cultivars did produce stalks within the bulbs. Garlic cultivars considered to be hardneck were less likely to produce scapes when conditions were such that small bulbs were produced. In addition, some plants of the softneck cultivar Silverwhite did produce a central stalk within bulbs when grown in Maryland. The direct causal factor in stalk formation within bulbs is not known; however, a mitochondrial marker associated with bolting has been described (Ipek et al., 2007).

The traits that varied across sites are recognized as less reliable for cultivar identification purposes, but instead make cultivars amenable or desirable for production in certain regions. It was not surprising to find that bulb size and circumference were highly site dependent and correlated. It has been previously reported that yield is correlated with bulb diameter, number of cloves, cloves diameter, and bulb weight (Panthee et al., 2006). Bulb wrapper color is also highly site-specific, supporting evidence reported by marketers that bulb color is more determined by growth environment than cultivar types (David Stern and Walt Lyons, personal communication).
These data can help farmers identify production-quality garlic for regional markets that provides novel products to consumers.

Some correlations were identified among high-yielding locations and soil conditions. In particular, sites with high potassium produced bulbs with significantly higher FWs and circumferences. Bulb elemental composition and soil nutrient content were significantly correlated only for manganese and sulfur. Garlic bulbs are $\approx 1 \%$ sulfur on a dry weight basis or $0.35 \%$ sulfur on a FW basis. Alliin, allicin, and two main $\gamma$-glutamylcysteines comprise roughly $72 \%$ of this sulfur (Lawson, 1993, 1996). The average clove sulfur observed in the present study is comparatively lower $(0.83 \%$ of dry weight) than this level.

Onions (Allium cepa L.) also vary by cultivar in response to soil fertility conditions. High sulfur fertility levels result in increased levels of sulfur compounds and greater flavor intensity (Coolong et al., 2004; Coolong and Randle, 2003; Huchette et al., 2007; Randle et al., 1995). In onion, mild flavors are produced when sulfur levels are sequentially reduced during bulb growth (Randle et al., 2002). Unlike in onion, detailed fertilizer regimes aimed at controlling garlic flavor intensity and pungency are not currently available for garlic.

Definitive cultivar recommendations for the participating states are not provided because the number of sites per region was limited. However, feedback from the participants does provide some guidance regarding cultivars that can do well in specific regions. At the conclusion of the project, the Vermont grower continued to grow eight of the 10 garlic cultivars in the project. 'Ajo Rojo' and 'Siberian' were particularly susceptible to disease in wet Vermont conditions. It is also noteworthy that both 'Red Janice' and 'Sakura' demonstrated improved yields in Vermont when grown for an additional year. In Pennsylvania, yields were high and all cultivars performed well with the exception of 'Spanish Roja'. Likewise, in Minnesota, all cultivars were marketable except 'Spanish Roja', 'Red Janice', and 'Ajo Rojo'. The Maryland grower was pleased with the performance of many diverse cultivars, especially 'Siberian', 'Inchelium', 'Sakura', and 'Red Janice', and the project confirmed previous observations that 'Spanish Roja' does not have high yields at the Maryland location. In Maryland, 'German White' performed rather poorly in comparison with other porcelain types usually grown. In Washington, all cultivars except 'Spanish Roja' and 'Sakura' will be grown in future years. 'Sakura' was a concern because bulb wrappers quickly deteriorate in the ground if it is not harvested within a short maturity window. Finally, in Nevada, 'German White' and 'Spanish Roja' did particularly poorly. Cultivars Red Janice, Sakura, and Purple Glazer were of particular interest for future Nevada production.

The demand for high-quality fresh market garlic continues to increase as restaurants and consumers seek to purchase local vegetables. Consumers are attracted to colorful, unique garlic types for different culinary purposes. As cultivar name recognition in garlic occurs, understanding which traits define specific cultivars and which traits are highly variable within cultivars will be valuable for successful marketing of new garlic cultivars.

\section{Literature Cited}

Al-Zahim, M., H.J. Newbury, and B.V. FordLloyd. 1997. Classification of genetic variation in garlic (Allium sativum L.) revealed by RAPD. HortScience 32:1102-1104.

Cathey, H.M. 1990. USDA plant hardiness zone map. USDA-ARS Misc. Pub. No. 1475.

Conci, V.C., A. Canavelli, P. Lunello, J. DiRienzo, S.F. Nome, G. Zumelzu, and R. Italia. 2003. Yield losses associated with virus-infected garlic plants during five successive years. Plant Dis. 87:1411-1415.

Coolong, T.W., D.A. Kopsell, D.E. Kopsell, and W.M. Randle. 2004. Nitrogen and sulfur influence nutrient usage and accumulation in onion. J. Plant Nutr. 27:1667-1686.

Coolong, T.W. and W.M. Randle. 2003. Sulfur and nitrogen availability interact to affect the flavor biosynthetic pathway in onion. J. Amer. Soc. Hort. Sci. 128:776-783.

Dickerson, G.W. and M. Wall. 1997. Varietal evaluation of garlic in New Mexico. New Mexico State University Agricultural Experiment Station Research Report 717.

Engeland, R.L. 1991. Growing great garlic. Filaree Productions, Okanogan, WA.

Engeland, R.L. 1995. Growing great garlic (suppl.). Filaree Productions, Okanogan, WA.

Etoh, T. 1985. Studies on the sterility in garlic, Allium sativum L. Mem. Fac. Agr. Kagoshima Univ. 21:77-132.

Hanelt, P. 2001. Mansfeld's encyclopedia of agricultural and horticultural crops (except ornamentals). Springer, Berlin, Germany.

Huchette, O., I. Arnault, J. Auger, C. Bellamy, L. Trueman, B. Thomas, S.J. Ochatt, and R. Kahane. 2007. Genotype, nitrogen fertility and sulphur availability interact to affect flavour in garlic (Allium sativum L.). J. Hort. Sci. Biotechnol. 82:79-88. 


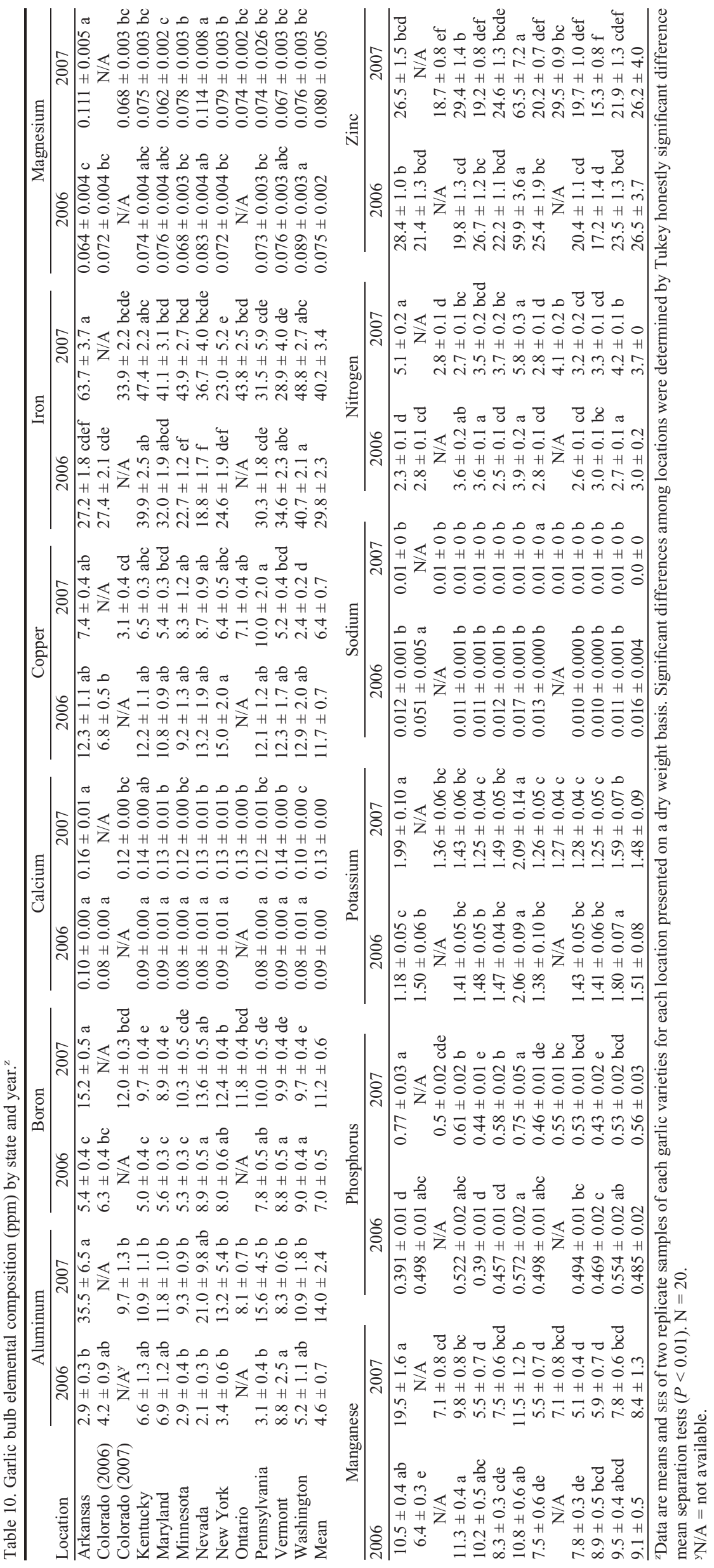

Ipek, M., A. Ipek, D. Senalik, and P.W. Simon. 2007. Characterization of an unusual cytoplasmic chimera detected in bolting garlic clones. J. Amer. Soc. Hort. Sci. 132:664-669.

Ipek, M., A. Ipek, and P.W. Simon. 2003. Comparison of AFLPs, RAPD markers, and isozymes for diversity assessment of garlic and detection of putative duplicates in germplasm collections. J. Amer. Soc. Hort. Sci. 128:246252.

IPGRI, ECP/GR, AVRDC. 2001. Descriptors for Allium (Allium spp.). International Plant Genetic Resources Institute, Rome, Italy; European Cooperative Programme for Crop Genetic Resources Networks (ECP/GR), Asian Vegetable Research and Development Center, Taiwan.

Jenderek, M.M. and R.M. Hannan. 2004. Variation in reproductive characteristics and seed production in the USDA garlic germplasm collection. HortScience 39:485-488.

Kamenetsky, R. 2007. Garlic: Botany and horticulture. Hort. Rev. (Amer. Soc. Hort. Sci.) 33:123-171

Kamenetsky, R. and H.D. Rabinowitch. 2001. Floral development in bolting garlic. Sex. Plant Reprod. 13:235-241.

Kamenetsky, R., I.L. Shafir, F. Khassanov, C. Kik, A.W. van Heusden, M. Vrielink-van Ginkel, K. Burger-Meijer, J. Auger, I. Arnault, and H.D. Rabinowitch. 2005. Diversity in fertility potential and organo-sulphur compounds among garlics from Central Asia. Biodivers. Conserv. 14:281-295.

Kamenetsky, R., I.L. Shafir, H. Zemah, A. Barzilay, and H.D. Rabinowitch. 2004. Environmental control of garlic growth and florogenesis. J. Amer. Soc. Hort. Sci. 129:144-151.

Keller, E.R.J. 2002. Cryopreservation of Allium sativum L. (garlic), p. 37-47. In: Towill, L.E. and Y.P.S. Bajaj (eds.). Biotechnology in agriculture and forestry, cryopreservation of plant germplasm II. Springer-Verlag, Berlin, Germany.

Lampasona, S.G., L. Martinez, and J.L. Burba. 2003. Genetic diversity among selected Argentenian garlic clones (Allium sativum L.) using AFLP (amplified fragment length polymorphism). Euphytica 132:115-119.

Lawson, L.D. 1993. Bioactive organosulfur compounds of garlic and garlic products: Role in reducing blood lipids, p. 306-330. In: Kinghorn, A.D. and M.F. Balandrin (eds.). Human medicinal agents from plants. Vol. ACS Symp. Ser. 534. Am. Chem. Soc. Books, Washington, DC. Chem. Abst. 119 (1993) 216610.

Lawson, L.D. 1996. The chemical composition and chemistry of garlic cloves and processed garlic, p. 37-107. In: Koch, H.P. and L.D. Lawson (eds.). Garlic. The science and therapeutic application of Allium sativum L. and related species. Williams \& Wilkins, Baltimore, MD

Lot, H., V. Chovelon, S. Souche, and B. Delecolle. 1998. Effects of onion yellow dwarf and leek yellow stripe viruses on symptomatology and yield loss of three French garlic cultivars. Plant Dis. 82:1381-1385.

Maaß, H.I. and M. Klaas. 1995. Infraspecific differentiation on garlic (Allium sativum L.) by isozyme and RAPD markers. Theor. Appl. Genet. 91:89-97.

Melo, P.D., R.O. Resende, C.M.T. Cordeiro, J.A. Buso, A.C. Torres, and A.N. Dusi. 2006. Viral reinfection affecting bulb production in garlic after seven years of cultivation under field conditions. Eur. J. Plant Pathol. 116:95-101.

Panthee, D.R., R.B. KC, H.N. Regmi, P.P. Subedi, S. Bhattarai, and J. Dhakal. 2006. Diversity 
analysis of garlic (Allium sativum L.) germplasms available in Nepal based on morphological characters. Genet. Resources Crop Evol. 53:205-212.

Pardo, J.E., J. Escribano, R. Gomez, and A. Alvarruiz. 2007. Physical-chemical and sensory quality evaluation of garlic cultivars. J. Food Qual. 30:609-622.

Pooler, M.R. and P.W. Simon. 1993a. Characterization and classification of isozyme and morphological variation in a diverse collection of garlic clones. Euphytica 68:121-130.

Pooler, M.R. and P.W. Simon. 1993b. Garlic flowering in response to clone, photoperiod, growth temperature, and cold-storage. HortScience 28:1085-1086.
Randle, W.M., D.E. Kopsell, and D.A. Kopsell. 2002. Sequentially reducing sulfate fertility during onion growth and development affects bulb flavor at harvest. HortScience 37:118-121.

Randle, W.M., J.E. Lancaster, M.L. Shaw, K.H. Sutton, R.L. Hay, and M.L. Bussard. 1995. Quantifying onion flavor compounds responding to sulfur fertility-sulfur increases levels of alk(en)yl cysteine sulfoxides and biosynthetic intermediates. J. Amer. Soc. Hort. Sci. 120: 1075-1081.

Rosen, C., R. Becker, V. Fritz, B. Hutchison, J Percich, C. Tong, and J. Wright. 2008. Growing garlic in Minnesota. Extension Bulletin. 18 June 2009. <http://www.extension.umn.edu/ distribution/cropsystems/DC7317.html>.
Shemesh, E., O. Scholten, H.D. Rabinowitch, and R. Kamenetsky. 2008. Unlocking variability: Inherent variation and developmental traits of garlic plants originated from sexual reproduction. Planta 227:1013-1024.

Stavelikova, H. 2008. Morphological characteristics of garlic (Allium sativum L.) genetic resources collection-Information. Horticultural Sci. 35:130-135.

Volk, G.M., A.D. Henk, and C.M. Richards. 2004. Genetic diversity among US garlic clones as detected using AFLP methods. J. Amer. Soc. Hort. Sci. 129:559-569.

Waterer, D. and D. Schmitz. 1994. Influence of variety and cultural practices on garlic yields in Saskatchewan. Can. J. Plant Sci. 74:611-614. 